\title{
EUROJUST CASEWORK ON MAFIA-TYPE CRIMINAL ORGANISATIONS
}

\author{
Marin Petkov ${ }^{1}$ and Dragomir Krastev ${ }^{2}$, \\ ${ }^{1}$ Assoc. Professor, Ph.D., National Military University, Veliko Tarnovo, Bulgaria, \\ marin_5kov@abv.bg \\ ${ }^{2}$ Assoc. Professor, Ph.D., National Military University, Veliko Tarnovo, Bulgaria, \\ drago.krastev@gmail.com
}

\begin{abstract}
Since 2012, more than 145 Eurojust cases dealt with Italian mafia-type OCGs, such as Cosa Nostra, Camorra and 'Ndrangheta. The casework at Eurojust confirms the transnational dimension of the Italian mafia-type OCGs, which over the years have consolidated their global partnerships with other criminal groups worldwide, active particularly in the areas of drug trafficking and money laundering.
\end{abstract}

Keywords: criminal organisations, Eurojust, security, crimes, police cooperation.

\section{INTRODUCTION}

"Organized criminal group" shall mean a structured group of three or more persons, existing for a period of time and acting in concert with the aim of committing one or more serious crimes or offences established in accordance with this Convention, in order to obtain, directly or indirectly, a financial or other material benefit;

Sub-definitions:

"Serious crime" shall mean conduct constituting an offence punishable by a maximum deprivation of liberty of at least four years or a more serious penalty;

"Structured group" shall mean a group that is not randomly formed for the immediate commission of an offence and that does not need to have formally defined roles for its members, continuity of its membership or a developed structure;

"Proceeds of crime" shall mean any property derived from or obtained, directly or indirectly, through the commission of an offence;

The term "Mafia", first used only to define a Sicilian phenomenon, is now used to describe any organized criminal group and it is certainly one of the words in the Italian language that is the best known and most used internationally.

This is not only due to the influence of the media, who tend to simplify reality with labels which are often 
incongruous and misleading. The phenomenon called "Mafia" as developed in Sicily, presents some characteristics which have made it a sort of paradigm, or frame of reference for similar organizations which have developed elsewhere in more recent times.

\section{EUROJUST CASEWORK ON MAFIA-TYPE CRIMINAL ORGANISATIONS}

Mass media represents the Mafia as a sort of universal Evil, the "octopus" that controls all criminal activities: from drug to arms trafficking and now even radioactive substances. In reality, the Sicilian Mafia can be considered a "winning model" of Organized Crime (at least until now) due to its complexity and long-standing role in society, but care must be taken against stereotypes that always see the octopus' tentacles everywere.

The Mafia's strength lies in its capacity to be both local and international and transnational, in the sense that it grew to a worldwide level without losing its roots in Sicilian society. Its strong-point has historically been the capacity to combine continuity with innovation: it has never abandoned its traditional activities (extortion for example) but knew how to choose the most profitable activities and become a part of them.

Mafia structure:

- Commissione (Cupola);

- Capo-mandamento;

- Capo famiglia (Cosca);

- Capo-decina;

- Picciotti/Soldati.

Characteristics of Mafia tipe organisations:

- Local origins;

- Evolution;

- Pyramidal structure;

- Ceremony of initiation;

- Code of honor;

- Intimidation and violence;

- Activities.

Anti-Mafia strategies:

- Creation of a Pool of Specialised Prosecutors;

- Adoption of Anti-Mafia Investigative Direction (DIA);

- Legislation to grant protection to those who collaborate with Prosecutors (PENTITI);

- Strict way of life sentence enforcement.

The three main Italian mafia-style groups - the Cosa Nostra, Camorra and Ndrangheta - operate worldwide but keep a very low profile outside of Italy, making it difficult for law enforcement agencies to detect these organised crime groups.

The power the Italian mafias have resides in their control and exploitation of territory and community. The concepts of family, power, respect and territory are fundamental to understanding the dynamics of the mafias. They are capable of manipulating elections and installing their people in administrative positions even in places far from the territories they control.

Money laundering and large-scale drug trafficking are the criminal focus of these groups. However, they are also involved in corruption, currency and goods counterfeiting, and the trafficking of toxic waste.

Particularly in periods of economic crisis, mafia groups can use their immense assets to easily infiltrate the legitimate economy. For instance, the Calabrian Ndrangheta takes in almost EUR 44 billion a year (2013). These huge sums allow the groups to inject much-needed liquidity into struggling businesses.

No legitimate business can afford to compete with criminal companies that can produce goods and services at a loss as part of a long-term strategy to take over markets. Thus, mafia groups have extended their presence into parts of Italy and Europe not historically affected by organised crime, a development that could 
have serious negative implications for the EU economy in the long run.

Since 2012, more than 145 Eurojust cases dealt with Italian mafia-type OCGs, such as Cosa Nostra, Camorra and 'Ndrangheta. The casework at Eurojust confirms the transnational dimension of the Italian mafia-type OCGs, which over the years have consolidated their global partnerships with other criminal groups worldwide, active particularly in the areas of drug trafficking and money laundering. In addition to laundering in foreign countries the proceeds of illicit activities carried out in Italy, these OCGs have massively infiltrated the legitimate economy of many Member States, such as Spain (particularly favoured by the Italian Camorra), the Netherlands, Romania, France, Germany and the UK, including through the presence in these Member States of dangerous Italian fugitives along with their networks of associates and facilitators. Such infiltrations are typically carried out directly by associates of the OCG or via its frontmen through real estate investments and participation in public or private contracts, particularly in the field of construction, public utilities and waste disposal. Under Italian criminal legislation, 'participation in a criminal organisation' is a stand-alone offence, punishable by long-term prison sentences under Articles 416 and 416bis of the Italian Criminal Code, as required by Article 2 of Council Framework Decision 2008/841/JHA on the fight against organised crime. Not all Member States, however, have adopted similar provisions incriminating 'participation in a criminal organisation' as a distinct offence. When they have done so, the extent of the application of and penalties attached to such offences varies greatly, and so do the possibility and requirements for applying special investigative techniques such as wiretappings. Experience shows that the existence of different legal definitions and the lack of an equivalent to Article 416bis of the Italian Criminal Code cause major legal and operational obstacles to effective judicial cooperation. Eurojust has supported successful operations by identifying judicial challenges and suggesting solutions, including enhancing the use of JITs, taking into account the different legal frameworks and prosecutorial approaches towards Italian OCGs existing at national level. The Italian authorities, with the support of the Italian Desk at Eurojust, have informed their counterparts in the Member States affected of the concrete threat posed by Italian mafia-type OCGs operating in their territory, as well as assisted in the identification and collection of evidence concerning the pre-requisite crime (frequently money laundering), and discussed and agreed on coordinated operational means to dismantle these groups, using special investigative techniques such as wiretappings, and, more recently, JITs. Several cases registered by the Italian National Desk are ongoing. An example of a case successfully supported by Eurojust demonstrates the challenges. An Italian investigation into a Camorra-affiliated OCG involved trading all sorts of counterfeited commodities (e.g. electric generators, chainsaws, drill hammers and clothing). The illicit products were produced in China, and counterfeit labels of well-known companies were attached in Italy. The goods were distributed all over the world via the Port of Naples. In addition, the electrical appliances and tools traded by the OCG did not comply with EU safety standards. The criminal activity was highly profitable (e.g. the price of an electric generator, produced in China for EUR 35, sold for EUR 400, while a legitimate brand would cost EUR 1250 ). The OCG was based in the vicinity of Naples, but its illicit operations stretched through more than twenty countries in Europe, as well as Australia and Iceland. Eurojust's coordination efforts helped the Italian and other national authorities to reconstruct the OCG and to reach a common understanding of how it operated at national level. A joint operational strategy and coordinated actions were agreed. The strategy was centred on opening and conducting national investigations of money laundering, in parallel with the original investigations for participation in a mafia-type OCG, conducted in Italy. Eurojust supported the parallel national investigations and the execution of more than 30 Italian MLA requests. The successful conclusion of the operations, coordinated via Eurojust, with the analytical support of Europol, culminated in simultaneous actions conducted in seven Member States (CZ, DE, ES, FR, IT, SE, UK), resulting in the arrest of 67 individuals, the search of 143 warehouses and the seizure of more than 800 tonnes of counterfeit materials and the recovery of assets exceeding EUR 11 million. Eurojust took note of the European Parliament's Resolution of 25 October 2016 on the fight against corruption and follow-up of the CRIM resolution calling for the Commission to submit a report assessing the transposition of Council Framework Decision 2008/841/JHA on the fight against organised crime.

In Europe and at the international level the problem is to elaborate a Penal Law against Organized Crime and to eliminate the conditions which encourage the development of Organized Crime. Few examples: to adopt the crime of Mafia-type association; to abolish the prohibition of drugs, the banking secrecy and other forms of opacity of the financial system. All these aspects are linked to the general context of the contemporary society.

Contradiction between legality and reality. An example: the prohibition of drugs was confirmed at the United Nations Convention of December 1988, but in spite of the tentatives to reduce the demand and stop drug trafficking, its use has increased and drug dealers have accumulated and continue to accumulate huge amounts of capital. The abolition of prohibition won't abolish the Mafia and the other foms of Organized 
Crime, that have other activities and would dedicate more time to them or find new ones, but would certainly hinder their capability to accumulate capital and would emancipate drug addicts from the slavery of drug dealers without scruples. For many years the debate on prohibition has been dominated by ethical and ideological concerns, but today the discussion places its attention mostly on concrete themes, like the costbenefit ratio of repressive measures, overcrowded prisons, paralysis of the judicial system, the diffusion of AIDS among drug addicts, the policy of "harm reduction".

\section{CONCLUSION}

If we want to tackle Organized Crime successfully, we must act in many directions:

Knowledge. We need an adequate knowledge of the evolution of Organized Crime and for that purpose it is necessary to find a network among various subjects: judicial offices, law enforcement agencies, parliamentary committees, research institutions etc.

International cooperation with the harmonization of legislation, procedures and law enforcement activities.

Prevention, acting on the structural causes of diffusion of Organized Crime: poverty, conveniences offered by the economy, connections with the institutions etc.

In this way the fight against Mafia and Organized Crime can become part of a global policy for democracy, co-existence and development, ensuring the satisfaction of basic needs for all human beings (Hristov, 2018a, pp.61-67; Hristov, Radulov, lliev, Andreeva, 2010a; Hristov, 2018b, pp. 183-186; Hristov, Ninov, 2018c, pp.316-323; Hristov, Naplatanova, 2018d, pp. 293-315; Hristov, 2017a, pp. 998-1004, Hristov, Georgiev, 2017b, , pp. 110 -113; Hristov, Georgiev, 2017c, , pp. 114-117; Hristov, Glushkov, 2018e, pp.582588; Hristov, Glushkov, 2018f, pp. 187-193; Hristov, 2017d, pp. 821-829; Madanski, Georgiev, 2017e, pp. 413; Madanski, Georgiev, 2017f, pp. 43-51; Terziev, Madanski, Georgiev, 2017g pp. 748-753; Terziev, Madanski, Georgiev, 2017h pp. 743-747; Terziev, Madanski, Georgiev, 2017i pp. 923-927; Terziev, Madanski, Georgiev, 2017j, pp. 1051-1055; Terziev, Nichev, Bankov, 2016a, s.189-196; Terziev, Nichev, Bankov, 2016b, s. s.116-134; Terziev, Nichev, Bankov, 2016c, pp.12-21; Terziev, Nichev, Bankov, 2016d, str.119-128; Terziev, Nichev, Bankov, 2016e, str.129-146; Terziev, Nichev, Bankov, 2016e, str.129-146; Terziev, Nichev, Bankov, 2016f, str. 144-185; Terziev, Nichev, Bankov, 2016f, str. 144-185; Terziev, Nichev, Bankov, 2016g, s.413-422; Terziev, Nichev, Bankov, 2016h, str.177-204; Nichev, 2017k, str. 121-128; Nichev, 2017l, pp. 129-135; Kanev, Terziev. 2017m; Kanev, Terziev, 2017n; Terziev, 2017o; Terziev, 2016i; Terziev, 2017p; Terziev, 2017q; Terziev, Vezieva, Arabska, 2016j; Terziev, Manolov, 2016k; Terziev, Minev, Sotirov, Ivanov, 2016I; Terziev, Kanev, 2017r; Terziev, Madanski, 2017s; Terziev, Madanski, 2017t; Terziev, Madanski, 2017u; Terziev, Madanski, Kanev, 2017v; Terziev, Madanski, Kanev, 2017w; Terziev, Madanski, Kanev, 2017x; Terziev, Madanski, Kanev, 2017y; Terziev, Madanski, Kanev, 2017z; Terziev, Nichev, 2016m; Terziev, Nichev, 2017).

\section{REFERENCE LIST}

Hristov, Neno. (2018a). Military Education as Possibility in Bulgaria. IJAEDU- International E-Journal of Advances in Education, Vol. IV, Issue 10, April 2018, pp.61-67.

Hristov, N., Radulov, I., lliev, P., Andreeva, P. (2010a). Prioritization Methodology for Development of Required Operational Capabilities. RTO-MP-SAS-081, 2010.

Hristov, Neno. (2018b). NATO Resilience, Deter and Professional Military Education. Proceedings of INTCESS 2018- 5th International Conference on Education and Social Sciences 5-7 February 2018Istanbul, Turkey, pp. 183-186.

Hristov, N, Ninov, M. (2018c). People's Character As a Prerequisite for the Albanian 'National Delay'. // 5th International Conference on Education, Social Sciences and Humanities, 2-4 July, 2018, ISBN: 978605-82433-3-0 316, pp.316-323.

Hristov, N, Naplatanova, G. (2018d). The Stereotypes of Military Towards Journalists and Work with Embedded Reporters in Missions and Operations Abroad. // 5th International Conference on Education, Social Sciences and Humanities, 2-4 July, 2018 - Dubai, ISBN: 978-605-82433-3-0, pp. 293-315. 
IJASOS- International E-Journal of Advances in Social Sciences, Vol. IV, Issue 11, August 2018

Hristov, Neno. (2017a). Bulgarian Experience in the Development of Military Concepts. // IJASOSInternational E-Journal of Advances in Social Sciences, Vol. III, Issue 9, December 2017, pp. 9981004.

Hristov, N., Georgiev, M. (2017b). Offset implementation impact on technology transfer in Bulgaria. // International Scientific Journal "Internauka". Izdatel' OOO «Finansovaya Rada Ukrainy», Kiyev, № 10 (32), 2017, pp. 110 -113, ISSN 2520-2057 (Hristov, N., Georgiev, M. Offset implementation impact on technology transfer in Bulgaria. // International Scientific Journal "Internauka". Издатель ООО «Финансовая Рада Украины», Киев, № 10 (32), 2017, pp. 110 -113, ISSN 2520-2057).

Hristov, N., Georgiev, M. (2017c). Offset as an economic operation and a trade practice. // International Scientific Journal "Internauka”. Izdatel' OOO «Finansovaya Rada Ukrainy», Kiyev, № 10 (32), 2017, pp. 114-117, ISSN 2520-2057 (Hristov, N., Georgiev, M. Offset as an economic operation and a trade practice. // International Scientific Journal "Internauka”. Издатель ООО «Финансовая Рада Украины», Киев, № 10 (32), 2017, pp. 114-117, ISSN 2520-2057).

Hristov, N., Glushkov, P. (2018e). Comparative Analysis of the Management Activity Training Of the Cadets, Studying in the Logistic Specializations. // Proceedings of INTCESS2018- 5th International Conference on Education and Social Sciences 5-7 February 2018- Istanbul, Turkey, pp.582-588.

Hristov, N., Glushkov, P. (2018f). Some Aspects Regarding the Display of the Organizational Activity at Work of the Logistic Officers. // Proceedings of INTCESS2018- 5th International Conference on Education and Social Sciences 5-7 February 2018- Istanbul, Turkey, pp.187-193.

Hristov, Neno. (2017d). Policy for Implementation of the Enterprise Architecture as a Tool in Bulgarian Mod. // The University of Sydney, 'History, Problems and Prospects of Development of Modern Civilization' The XX International Academic Congress (Australia, Sydney, 18-20 July 2017) Papers and commentaries Volume XX, ISBN: 978-0-578-84563-7, pp. 821-829.

Madanski, V., Georgiev, M. (2017e). The offset as a specific sort of economic activity. // Scientific journal «Economics and finance». Academic publishing house of the Agricultural University, Priority research areas: Collection of scientific articles, 2017, pp. 4-13, ISBN 978-617-7214-53-2.

Madanski, V., Georgiev, M. (2017f). Study of the effect of offset implementation on technology transfer in the Republic of Bulgaria. // Scientific journal «Economics and finance». Academic publishing house of the Agricultural University, Priority research areas: Collection of scientific articles, 2017, pp. 43-51, ISBN 978-617-7214-53-2.

Terziev, V., Madanski, V., Georgiev, M. (2017g). Offset as an economic operation and a trade practice. // Proceedings of ADVED 2017- 3rd International Conference on Advances in Education and Social Sciences 9-11 October 2017- Istanbul, Turkey. International Organization Center of Academic Research, www.ocerint.org, 2017, pp. 748-753, ISBN: 978-605-82433-0-9.

Terziev, V., Madanski, V., Georgiev, M. (2017h). Offset implementation impact on technology transfer in Bulgaria. // Proceedings of ADVED 2017- 3rd International Conference on Advances in Education and Social Sciences 9-11 October 2017- Istanbul, Turkey .International Organization Center of Academic Research, www.ocerint.org, 2017, pp. 743-747, ISBN: 978-605-82433-0-9.

Terziev, V., Madanski, V., Georgiev, M. (2017i). Offset implementation impact on technology transfer in Bulgaria. // IJAEDU- International E-Journal of Advances in Education, International Organization Center of Academic Research, www.ocerint.org, 3, 2017, N 9, pp. 923-927, e-ISSN: 2411-18.

Terziev, V., Madanski, V., Georgiev, M. (2017j). Offset as an economic operation and a trade practice. // IJAEDU- International E-Journal of Advances in Education, International Organization Center of Academic Research, www.ocerint.org, 3, 2017, N 9, pp. 1051-1055, e-ISSN: 2411-18.

Terziev, V., Nichev, N., Bankov, S. (2016a). Corruption and national security. // Mezhdunarodnyy nauchnnyy zhurnal Inovatsionnaya nauka, №10-3/2016, Chastyakh 3, Ufa, Rossiya, ISSN 2410-6070, s.189-196 (Terziev, V., Nichev, N., Bankov, S. Corruption and national security. // Международный научнный журнал Иновационная наука, №10-3/2016, Частях 3, Уфра, Россия, ISSN 2410-6070, с.189-196).

Terziev, V., Nichev, N., Bankov, S. (2016b). Essence and reasons for the manifestation and basic areas of corruption and government structures for corruption counteraction in Bulgaria. // Sbornik nauchnykh trudov „Novyy vzglyad”: Mezhdunarodnyy nauchnyy vestnik: sbornik nauchnykh trudov. Vypusk 15 / Pod obshch. red. S.S. Chernova. - Novosibirsk: Izdatel'stvo TSRNS, 2016. - 166 s., ISBN 978-500068-714-7, s.116-134 (Terziev, V., Nichev, N., Bankov, S. Essence and reasons for the 
manifestation and basic areas of corruption and government structures for corruption counteraction in Bulgaria. // Сборник научных трудов „Новый взгляд”: Международный научный вестник: сборник научных трудов. Выпуск 15 / Под общ. ред. С.С. Чернова. - Новосибирск: Издательство ЦРНС, 2016. - 166 c., ISBN 978-5-00068-714-7, c.116-134).

Terziev, V., Nichev, N., Bankov, S. (2016c). National security of the republic of Bulgaria. // Science and practice: Collection of scientific articles. Thoroe-Bowker, Melbourne, Australia, 2016, ISBN 978-09942661-3-2, pp.12-21.

Terziev, V., Nichev, N., Bankov, S. (2016d). Tipichni modeli na razsledvanena koruptsiyata sred politseyski sluzhiteli. // Sbornik dokladi: Godishna universitetska nauchna konferentsiya, 20-21 oktomvri 2016 g., NVU „Vasil Levski“ - Veliko Tarnovo., Nauchno napravlenie „Sotsialni, stopanski i pravni nauki“, 7, 2016, ISSN 1314-1937, str.119-128 (Терзиев, В., Ничев, Н., Банков, С. Типични модели на разследванена корупцията сред полицейски служители. // Сборник доклади: Годишна университетска научна конференция, 20-21 октомври 2016 г., НВУ „Васил Левски“ - Велико Търново., Научно направление „Социални, стопански и правни науки“, 7, 2016, ISSN 1314-1937, стр.119-128).

Terziev, V., Nichev, N., Bankov, S. (2016e). Nakazatelno pravni aspekti na koruptsiyata i ustanoveni praktiki v Balgariya. // Sbornik dokladi: Godishna universitetska nauchna konferentsiya, 20-21 oktomvri 2016 g., NVU „Vasil Levski“ - Veliko Tarnovo., Nauchno napravlenie „Sotsialni, stopanski i pravni nauki“, 7, 2016, ISSN 1314-1937, str.129-146 (Терзиев, В., Ничев, Н., Банков, С. Наказателно правни аспекти на корупцията и установени практики в България. // Сборник доклади: Годишна университетска научна конференция, 20-21 октомври 2016 г., НВУ „Васил Левски“ - Велико Търново., Научно направление „Социални, стопански и правни науки“, 7, 2016, ISSN 1314-1937, стр.129-146).

Terziev, V., Nichev, N., Bankov, S. (2016f). Prilozhenie na efektivna metodika na razsledvane na koruptsiyata sred politseyskite sluzhiteli v Balgariya. // Godishnik na NVU „Vasil Levski“, NVU „Vasil Levski“- Veliko Tarnovo, Izdatelski kompleks na NVU „Vasil Levski”, 2015, ISSN 1312-6148, str.144185 (Терзиев, В., Ничев, Н., Банков, С. Приложение на ефективна методика на разследване на корупцията сред полицейските служители в България. // Годишник на НВУ „Васил Левски“, НВУ „Васил Левски“- Велико Търново, Издателски комплекс на НВУ „Васил Левски”, 2015, ISSN 1312-6148, стр.144-185).

Terziev, V., Nichev, N., Bankov, S. (2016g). Razrabotvane na metodika na razsledvane na koruptsiyata sred politseyskite sluzhiteli v Balgariya. II XI Mezhdunarodnoy nauchnoy konferentsii „Innovatsii v tehnologiyah i obrazovanii“, 18-19 Marta 2016 g., Sbornik statey: chasty 3, Belovo- Veliko-tayrnovo, 2016, Kuzbasskiy gosudarstvennayy tehnicheskiy universitet imeni T.F. Gorbacheva Velikotayrnovskiy universitet im. Svyatayh. Kirilla i Mefodiya Filial KuzGTU v g. Belovo Vaysshaya shkola agrobiznesa i razvitiya regionov, Plovdiv, 2016, s.413-422, ISBN 978-5-906888-03-7 (Терзиев, В., Ничев, Н., Банков, С. Разработване на методика на разследване на корупцията сред полицейските служители в България. // XI Международной научной конференции „Инновации в технологиях и образовании“, 18-19 Марта 2016 г., Сборник статей: часть 3, Белово- Велико-тырново, 2016, Кузбасский государственный технический университет имени Т.Ф. Горбачева Великотырновский университет им. Святых. Кирилла и Мефодия Филиал КузГТУ в г. Белово Высшая школа агробизнеса и развития регионов, Пловдив, 2016, с.413-422, ISBN 978-5-906888-03-7).

Terziev, V., Nichev, N., Bankov, S. (2016h). Prilozhenie na efektivna metodika na razsledvane na koruptsiyata sred politseyskite sluzhiteli v Balgariya. // Sbornik dokladi: Parva nauchna konferentsiya po sotsialno predpriemachestvo. Saveti, umeniya i instrumenti za konsultirane na sotsialnite predpriemachi, Proekt : Umeniya za biznes konsultanti v oblastta na sotsialnoto predpriemachestvo, International scientific conference 29 September 2016, Plovdiv, Bulgaria, Agraren Universitet Plovdiv, 2016, ISBN 978-954-517-249-6 (CD), ISBN 978-954-517-250-2 (Print), str.177-204 (Терзиев, В., Ничев, Н., Банков, С. Приложение на ефективна методика на разследване на корупцията сред полицейските служители в България. // Сборник доклади: Първа научна конференция по социално предприемачество. Съвети, умения и инструменти за консултиране на социалните предприемачи, Проект : Умения за бизнес консултанти в областта на социалното предприемачество, International scientific conference 29 September 2016, Plovdiv, Bulgaria, Аграрен Университет Пловдив, 2016, ISBN 978-954-517-249-6 (CD), ISBN 978-954-517-250-2 (Print), стр.177-204).

Nichev, N. (2017k). Ofsetna politika na stranite ot Evropeyskiya Sayuz. Spisanie za nauka "Novo znanie”, 
Akademichno izdatelstvo „Talant“, Visshe uchilishte po agrobiznes i razvitie na regionite, Plovdiv, Vol 6, No 1, 2017, str. 121-128, ISSN 2367-4598 (Online), ISSN 1314-5703 (Print) (Ничев, Н. Офсетна политика на страните от Европейския Съюз. Списание за наука „Ново знание”, Академично издателство „Талант“, Висше училище по агробизнес и развитие на регионите, Пловдив, Vol 6 , No 1, 2017, стр. 121-128, (Online) ISSN 2367-4598, (Print) ISSN 1314-5703).

Nichev, N. (2017l). Perspektivi za izpolzvane na ofsetnite sdelki. Spisanie za nauka „Novo znanie”, Akademichno izdatelstvo „Talant", Visshe uchilishte po agrobiznes i razvitie na regionite - Plovdiv, Vol 6, No 1, 2017: pp. 129-135, (Online) ISSN 2367-4598, (Print) ISSN 1314-5703 (Ничев, Н. Перспективи за използване на офсетните сделки. Списание за наука „Ново знание”, Академично издателство „Талант“, Висше училище по агробизнес и развитие на регионите Пловдив, Vol 6, No 1, 2017: pp. 129-135, (Online) ISSN 2367-4598, (Print) ISSN 1314-5703).

Kanev, D.,Terziev. V. (2017m). Behavioral economics: development, condition and perspectives. // IJASOSInternational E-Journal of Advances in Social Sciences, Vol. III, Issue 8, e-ISSN: 2411-183X.

Kanev, D.,Terziev. V. (2017n). Behavioral economics: development, condition and perspectives. // Proceedings of SOCIOINT 2017- 4th International Conference on Education, Social Sciences and Humanities 10-12 July 2017- Dubai, UAE, ISBN: 978-605-82433-1-6.

Sotirov, B., Terziev, V. (2015a). Predizvikatelstva i perspektivi pred obuchenieto po tehnologichni distsiplini. // Parva mezhdunarodna nauchna konferentsiya „Predizvikatelstva pred savremennite organizatsii, svarzani s postigane na ustoychivost - znanie i inovatsii v upravlenieto i funktsioniraneto",Plovdiv. ISBN 978-619-7246-04-9 (DVD), ISBN 978-619-7246-06-3 (e-book).

Sotirov, B., Terziev, V. (2015b). Challenges and perspectives to the training in technological subjects. // Book of Abstracts: First International Scientific Conference "Sustainability Challenges in Modern Organizations - Knowledge \& Innovation in Management \& Operation", ISBN 978-619-7246-03-2 (DVD), ISBN 978-619-7246-05-6 (e-book).

Terziev. V. (20170). National security of the republic of Bulgaria. // The Chinese Journal of International Politics, №1(10), ISSN 1750-8916.

Terziev. V. (2016i). Human resource management systems in security and defense: social policies for social activities. // XXXII Mezhdunarodnaya nauchno-prakticheskaya konferentsiya, Evraziyskiy soyuz uchenayh (ESU), Ezhemesyachnayy nauchnayy zhurnal № 12 (33)/ 2016 Chasty 1, Moskva 30.12.2016g., ISSN 2411-6467.

Terziev. V. (2017p). Entry Opportunities in the Bulgarian Military - Educational System and Ensuring of Civil Rights. // 3rd Central and Eastern European LUMEN International Scientific Conference New Approaches in Social and Humanistic Sciences 8-10 June 2017 | Chisinau, Republic of Moldova, ISBN: 978-973-166-461-3.

Terziev. V. (2017q). National security of the republic of Bulgaria. // International Journal of Management and Applied Science, Volume-3, Issue-4, ISSN: 2394-7926.

Terziev, V., Vezieva. V., Arabska, A. (2016j). Balgarskite universiteti i vazmozhnostite na Operativna programa „Nauka i obrazovanie za inteligenten rastezh". // Mezhdunarodna nauchna konferentsiya „Obrazovanie, nauka, ikonomika i tehnologii“ 23-24 yuni 2016 g. Akademichno spisanie „Upravlenie i obrazovanie“ Tom XII(1) 2016, ISSN 1312-6121.

Terziev, V., Manolov.D. (2016k). Sazdavane na dobra organizatsionna sreda za nauchnoizsledovatelska deynost (Creation of good organizational environment for scientific research activity), Aktual'nyye problemy globalizatsii. // Saloniki, Gretsiya (Actual problems of globalization, August 29, 2016, Thessaloniki, Greece), Scientific journal „ECONOMICS AND FINANCE“, Actual problems of globalization - Collection of scientific articles, ISBN 978-617-7214-34-1.

Terziev, V., Minev, R., Sotirov, B., Ivanov, K. (2016I). Vazmozhnosti za izgrazhdane na tsentar za kompetentnost $v$ Severen tsentralen rayon na Republika Balgariya. // Godishna universitetska nauchna konferentsiya, 20-21 oktomvri 2016 g. NVU „Vasil Levski“- Veliko Tarnovo. Sbornik dokladi tom 2, Nauchni napravleniya „Prirodomatematicheski nauki” i „Tehnicheski nauki”, ISSN 1314-1937.

Terziev. V., Kanev, D. (2017r). Education and Behavioural Failures. // Proceedings of ADVED 2017- 3rd International Conference on Advances in Education and Social Sciences 9-11 October 2017- Istanbul, Turkey, ISBN: 978-605-82433-0-9.

Terziev, V, Madanski, V. (2017s). Development of military education system in Bulgaria (Razvitie na 
voennoobrazovatelnata sistema $v$ Balgariya). // Topical questions of contemporary science, United States of America 2017, ISBN 978-0-9988732-1-3.

Terziev, V, Madanski, V. (2017t). Guidelines for development of military education system in Bulgaria (Nasoki za razvitie na voennoobrazovatelnata sistema na Balgariya). // Topical questions of contemporary science, United States of America 2017, ISBN 978-0-9988732-1-3.

Terziev, V, Madanski, V. (2017u). Guidelines for development of military education system in Bulgaria. // Proceedings of the VII International Academic Congress "Fundamental and Applied Studies in EU and CIS Countries" (United Kingdom, Cambridge, England, 26-28 February 2017). Volume VII. Cambridge University Press, 2017, ISBN: 978-0-875-83597-4.

Terziev, V, Madanski, V., Kanev, D. (2017v). Entry opportunities in the bulgarian military-educational system and ensuring of civil rights. // Proceedings of SOCIOINT 2017- 4th International Conference on Education, Social Sciences and Humanities 10-12 July 2017- Dubai, UAE, ISBN: 978-605-82433-1-6.

Terziev, V, Madanski, V., Kanev, D. (2017w). Entry opportunities in the bulgarian military-educational system and ensuring of civil rights. // IJAEDU- International E-Journal of Advances in Education, Vol. 3, Issue 8, August 2017, e-ISSN:2411-1821.

Terziev, V, Madanski, V., Kanev, D. (2017x). Entry opportunities in the Bulgarian military-educational system. // Sport, Education and Society, Issue 8 (2), Volume 22. Taylor \& Francis, Print ISSN: 1357-3322 Online ISSN: 1470-1243.

Terziev, V, Madanski, V., Kanev, D. (2017y). Condition and capabilities of the military-educational system of the Republic of Bulgaria. // Sport, Education and Society, Issue 8 (2), Volume 22. Taylor \& Francis, Print ISSN: 1357-3322 Online ISSN: 1470-1243.

Terziev, V, Madanski, V., Kanev, D. (2017z). Directions for improvement of the military-educational system and its contribution for strengthening national security and the defence of the country. // Sport, Education and Society, Issue 8 (2), Volume 22. Taylor \& Francis, Print ISSN: 1357-3322 Online ISSN: 1470-1243.

Terziev, V., N.Nichev. (2016m). Ikonomicheski harakteristiki na ofestnite sdelki s otrbranitelni produkti. // Scientific journal „Economics and Finance”, Problems of development modern science: Theory and practice - Collection of scienfic articles, pp.101-106.

Terziev. V., N.Nichev. (2017). Osnovni harakteristiki na kompensaciite v tyrgoviqta s otbrana. // Proceedings of SOCIOINT 2017- 4th International Conference on Education, Social Sciences and Humanities, pp.661-666. 